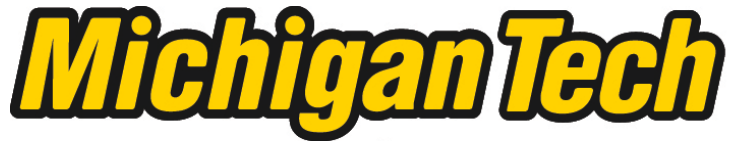 \\ Michigan Technological University Create the Future Digital Commons @ Michigan Tech
}

2011

\section{Understanding Michigan nonindustrial private forest landowners attitudes and knowledge about forest management}

Tõnis Tõnisson

Michigan Technological University

Follow this and additional works at: https://digitalcommons.mtu.edu/etds

Part of the Forest Sciences Commons

Copyright 2011 Tõnis Tõnisson

\section{Recommended Citation}

Tõnisson, Tõnis, "Understanding Michigan nonindustrial private forest landowners attitudes and knowledge about forest management", Master's report, Michigan Technological University, 2011. https://doi.org/10.37099/mtu.dc.etds/155

Follow this and additional works at: https://digitalcommons.mtu.edu/etds

8 Part of the Forest Sciences Commons 


\title{
UNDERSTANDING MICHIGAN NONINDUSTRIAL PRIVATE FOREST LANDOWNERS ATTITUDES AND KNOWLEDGE ABOUT FOREST MANAGEMENT
}

\author{
By
}

Tõnis Tõnisson

\begin{abstract}
A REPORT
Submitted in partial fulfillment of the requirements for the degree of MASTER OF SCIENCE

Forestry
\end{abstract}

MICHIGAN TECHNOLOGICAL UNIVERSITY

2011

(C2011 Tõnis Tõnisson 
This report, “Understanding Michigan Nonindustrial Private Forest Landowners Attitudes and Knowledge about Forest Management,” is hereby approved in partial fulfillment of the requirements for the Degree of MASTER OF SCIENCE IN FORESTRY.

School of Forest Resources and Environmental Science

Signatures:

Report Advisor

Kathleen E. Halvorsen

Dean

Margaret R. Gale

Date 


\section{Table of Contents}

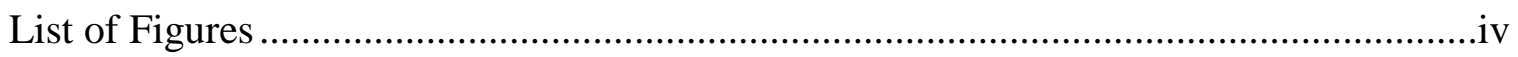

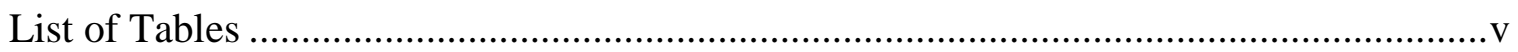

Acknowledgements .................................................................................................

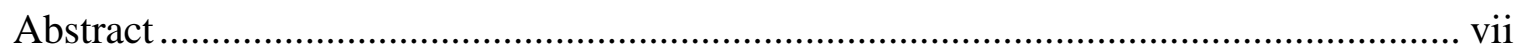

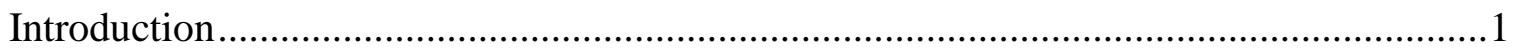

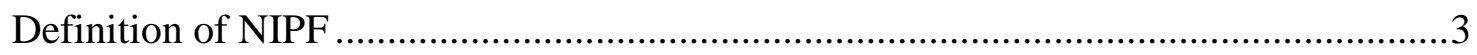

Michigan family forest owners and their forest holdings .................................................

Reasons for owning forestlands ................................................................................

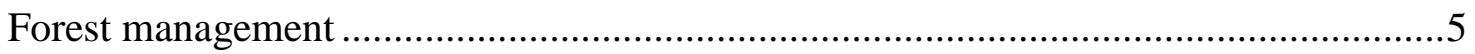

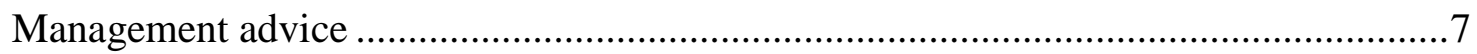

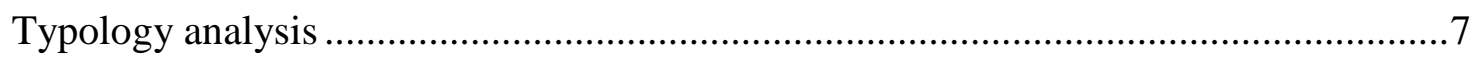

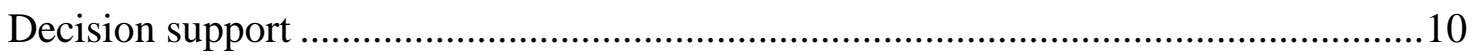

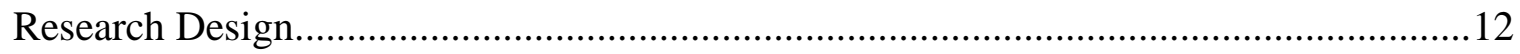

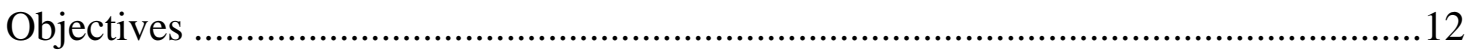

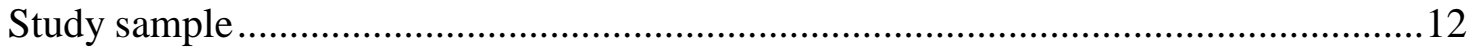

Interviews, data collection ……………………….........................................13

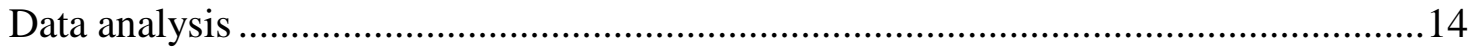

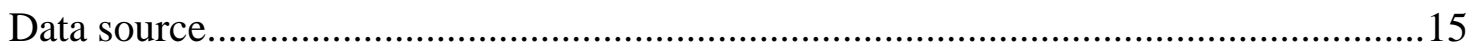

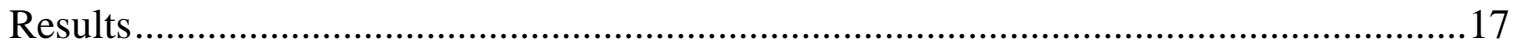

Landowners' motivations towards forestry ………….................................................18

Landowners and forest management practices .............................................................22

Landowners and their knowledge in forestry..............................................................26

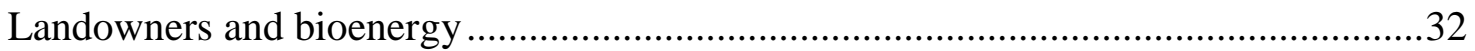

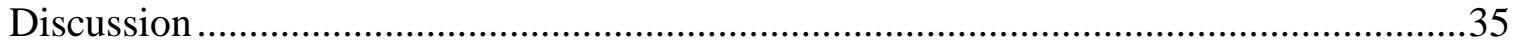

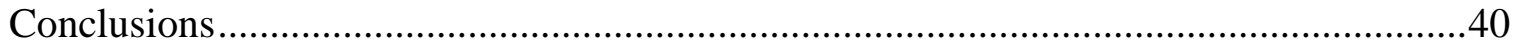

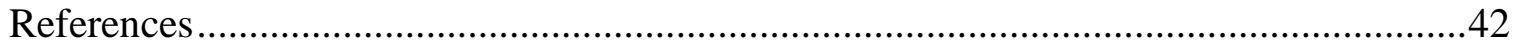

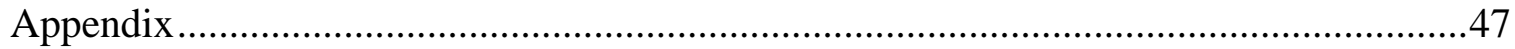




\section{List of Figures}

Figure 1. Hypothetical continuum of landowners' dependence on professional advice

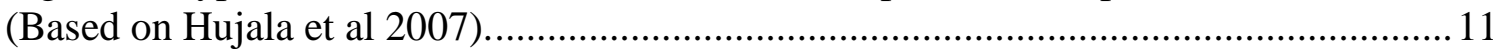




\section{List of Tables}

Table 1. Selection of landowners' typology groups (Based on Ní Dhubháin et al 2007). .9 Table 2. Landowners preference for healthy mature forests in the Great Lakes area

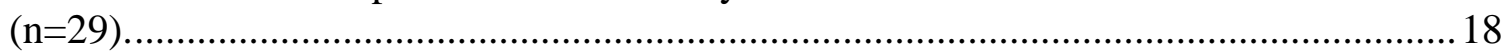

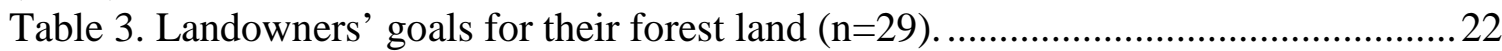

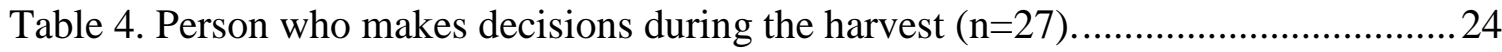

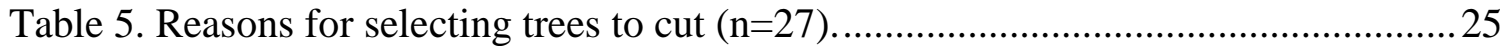

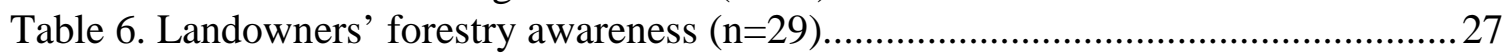

Table 7. Advantages and disadvantages of managing forest for timber $(n=30)$............. 29

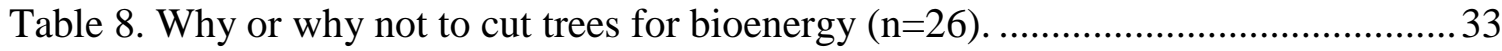




\section{Acknowledgements}

I am grateful to the EU-USA funded ATLANTIS dual degree program for giving me this wonderful opportunity to study in Sweden, Finland and USA. Support for the current study was provided by the Michigan Economic Development Council's Center for Energy Excellence grant to lay the groundwork for establishment of Mascoma Corporation’s Frontier Resources cellulosic ethanol plant in Kinross, Michigan.

My greatest thanks to my advisor at MTU, Kathleen E. Halvorsen for her guidance, support and patience throughout time I spent at Houghton.

I thank Vilis Brukas of being my co-advisor at SLU and for his constructive advice I have received during my studies.

I would like to thank my committee members Robert E. Froese, Adam M. Wellstead and Ola Sallnäs.

I wish to thank all the ATLANTIS program advisors Eric Agestam, Maija Kovanen and Shekhar Joshi for guiding me during the admission procedures.

Thank you to Lauren N. Dupey for all of your assistance, contribution and help to make this report possible. 


\section{Abstract}

Approximately one-fourth of the non-industrial private forestland (NIPF) owners in the state of Michigan, who collectively own approximately $50 \%$ of the private forested land, have conducted commercial timber harvest in recent years. Previous studies indicated that NIPFs preferred to manage their forest for a sustained yield of high-quality timber, but were limited to even-aged regeneration treatments or conversion for uneven-aged silviculture due to previous cuttings. Improved knowledge about NIPF's intentions and forest management behavior could be useful for successful implementation of sustained yield management. This study's objective was to identify more active NIPF's attitudes towards timber management, their forest management practices and whether their forest management behavior leads or leads not to q management for sustained yield. Active NIPF's intentions to harvest timber for biofuels and its suitability with NIPF's forest management behavior will be discussed. Phone interviews of 30 NIPFs who have experience with commercial timber harvests were conducted between August and October 2011. All interviews were recorded, transcribed, and analyzed for identifying NIPF’s motivations, attitudes, forest management behavior and forestry related knowledge. Interviewees, whether consciously or not, tended to manage their land for a sustained yield and they would be willing to harvest timber for biofuels facility as long as it benefits landowners management goals. 


\section{Introduction}

Forest management includes the provision of wood and non-wood products, environmental protection and services such as recreation, maintenance of biodiversity, and carbon sequestration (Butler and Leatherberry 2004). In the United States, a significant portion of forest-related economic, environmental and social services are provided on private land (Butler and Leatherberry 2004).

The demand for renewable energy is expected to continue in future. Renewable resources such as biomass help to reduce energy dependence on fossil fuel based chemicals. The Mascoma Corporation is developing and building a facility to produce cellulosic ethanol from hardwoods (Mascoma Corporation 2011). The plant is located in Kinross (in Michigan’s eastern Upper Peninsula) and the potential resource for raw material is expected to be within a 150 mile supply radius (Makinen 2010). Approximately half of Michigan's timberland is held by private non-industrial forest landowners (NIPFs) (Leatherberry et al 1998), therefore a supply of woody biomass from NIPFs is necessary for successful implementation of new bioenery facility.

Michigan has 18.7 million acres of forest available for harvesting (Hansen and Brand 2006). These are predominantly hardwood forests (75\% of the timberland area) and the main forest types are: sugar maple/beech/yellow birch, aspen, hard maple/basswood and white oak/red oak/hickory (Hansen and Brand 2006). Among the softwoods, the most extensive forest type is northern white-cedar (Hansen and Brand 2006). 
Typically the selection cutting method with modifications is preferred for managing the northern hardwoods (Arbogast 1957; Tubbs 1977). To achieve desired management objectives growth, yield, regeneration and diameter distribution is necessary to control stand density and structure (Nowak and Marquis 1997). An all-aged system of sustained yield management is defined as forest management which aims for a stand with continuous production of high quality trees (Arbogast 1957) at the earliest stage as possible (Munsell et al 2009). To achieve a high quality stand and sustained yield of timber production it is necessary to remove trees with undesirable properties over the entire range of size classes, and remove the mature and overly mature trees (Arbogast 1957). Cutting cycles should be relatively short (8 to 15 years) and done as a consistent series (Arbogast 1957; Tubbs 1977). Usually sustainable forestry is altered with diameter-limit cutting where smaller trees are left behind and larger trees are removed, or with high-grading where poor-quality stems and species without commercial value are not removed (Kenefic and Nyland 2005). Hyberg (1987) suggests that poor forest management on private lands could be related to a lack of management alternatives being offered to NIPFs.

Munsell et al.'s (2009) study about New York NIPFs found that they have positive intentions of managing their forests for a sustained yield of high quality timber. However, achieving sustained yield management was hampered on most of the studied forest holdings due to previous harvest practices (Munsell et al 2009). Most of the case study NIPF's needed to include regeneration harvesting to achieve a sustained yield (Munsell et al 2009). A sustained yield management case study about NIPFs in 
Mississippi and New York by Munsell et al (2008) found that future timber supply among NIPF's in New York is hampered due to premature cutting, over thinning and absence of regeneration.

This research aims to improve our knowledge about NIPF's intentions to manage forest for a sustained yield and woody biomass availability from their land. I will look to answer the question: How timber harvest for biofuels can be combined with sustained yield management on NIPF lands? Furthermore, I hope to define landowners' knowledge about forestry and how the decisions regards to forest management are made.

\section{Definition of NIPF}

This report concentrates on individual or "family" (couples) forest owners, who are a subset of NIPFs and this group is defined as families and individuals that own forest land (Butler 2008). Butler et al. (2007) looked at family forest owners who owned less than 10 acres as large house lot owners without any ambition to manage their forest, and owners who owned 1,000 acres or more as landowners with proactive intentions of managing their land consciously.

\section{Michigan family forest owners and their forest holdings}

Landowner characteristics (age, education, tenure of ownership, holding size,

place of residence) are often used for predicting their forest management behavior. Forest owners in the state of Michigan are relatively old (average 59 years), well educated (at least some college or higher) and have owned their land for approximately 35 years (Potter-Witter 2005). Age is found to be inversely related to timber harvest decisions and engagement of habitat management (Joshi and Arano 2009). This means younger 
landowners are more likely to do timber harvests, managing habitat and improving recreational activities (Joshi and Arano 2009). Joshi and Arano (2009) also found that landowners with higher education are more often involved with timber harvesting and engaged in silvicultural activities. In contrast to Joshi and Arano (2009) findings, PotterWitter (2005) found that landowner age and education did not significantly explain whether a parcel was managed. Landowners who have owned their land for longer time periods tend to be more timber oriented and are more frequently to carry out harvest operations (Butler et al 2007; Majumdar et al 2008). A study by Pan et al (2007) found that an increased length of land tenure resulted in larger holding sizes. Butler et al. (2007) suggest that forest management demands long-term decisions. Therefore, owners engaged in timber production are associated longer with their land than owners who use it for recreation and aesthetic values.

Michigan NIPFs own an average of 34.1 acres of forest land. About two-thirds of the landowners, holding $47 \%$ of the timberland have their primary residence within a mile of their land (Leatherberry et al 1998). Previous studies have shown that forest holding size is positively correlated with landowners' likelihood to harvest timber, the presence of a forest management plan and use of forest management advice from professionals (Butler et al 2007; Butler 2008; Majumdar et al 2008). Larger parcel size also indicates higher motivation for both monetary (hunting, timber) and non-monetary (aesthetics, biodiversity) values (Majumdar et al 2008). Landowners who do not reside on their land tend to be timber oriented and more often harvesting timber on their land (Majumdar et al 2008). 


\section{Reasons for owning forestlands}

Ericson et al (2002) found that Michigan landowners mostly value aesthetics and environmental protection on their land. The highest rated individual items for those categories were "wildlife” and "to add beauty" (Ericson et al 2002). According to the National Woodland Owner Survey (NWOS) only seven percent of family forest owners who hold $18 \%$ of the forest land reported timber production as a primary reason for owning the forest land (USFS 2011). The NWOS is a survey of private forest owners in United States and all subsequent percentages are calculated based on data from a NWOS internet based table maker. NIPFs with timber related objectives tend to be involved in timber harvest, silvicultural and property management activities (Joshi and Arano 2009). This is also true for landowners with non-timber primary objectives (Joshi and Arano 2009). Landowners with non-timber objectives tend to be engaged in habitat management and improving recreational activities (Joshi and Arano 2009).

\section{Forest management}

Landowners in the state of Michigan mostly see themselves as hands-off managers with a trend of "letting nature take its course” (Ericson et al 2002). Property owners are engaged with cutting dead trees and maintaining trails on their land (Ericson et al 2002). Planting trees and selective cutting are management practices which do not occur often on NIPF's lands (Ericson et al 2002). According to Joshi and Arano (2009) at least half of the landowners have practiced some kind of management activity (property management, silvicultural activities, wildlife, habitat management, recreational improvement and timber harvesting). 
Forty-three percent of the family forest owners in the state of Michigan who hold 63\% of the forest land area have reported timber harvesting on their land (USFS 2011). Commercial timber harvest is reported by $24 \%$ of family forest owners who hold $51 \%$ of the forest land area (USFS 2011). The most common reasons for timber harvest were: improving quality of remaining trees, maturity of trees, removing damaged trees and using wood for personal use (USFS 2011). Other frequent management activities among the landowners in the state of Michigan were: private recreation, posting land, tree planting and road or trail maintenance (USFS 2011). Joshi and Arano (2009) found that landowners who are actively managing their land are involved in multiple management activities.

Only three percent of the property owners (who hold $11 \%$ of the forest land) have reported the presence of a written forest management plan (USFS 2011). Joshi and Arano (2009) confirmed a positive correlation between a written forest management plan and engagement in forest management activities. Twenty-nine percent of the landowners who own $46 \%$ of the private forest land consulted with a forester during the timber harvest (USFS 2011). A study by Pan et al (2007) found that the forest holding size were positively correlated to the probability for timber harvest, having a forest management plan and having management advice. That means landowners with larger parcel size were more likely to harvest timber, have a written forest management plan and sought for management advice than landowners with smaller parcels. Landowners tend to be involved in forest management when they hold larger parcels because of increased incentives and opportunities for management (Pan et al 2007). 


\section{Management advice}

According to the NWOS, $15 \%$ of Michigan landowners reported receiving any type of management advice (USFS 2011). The most common sources for advice were: private consultant, logger, federal agency, state forestry agency and extension (USFS 2011). Most commonly preferred sources for receiving management advice were: publications, newsletters, consultation with a forester, internet and videos (USFS 2011). Salmon et al (2006) found that the most common source of forestry information for amenity focused, multiple-benefit, passive landowners were friends and relatives. Landowners with less forestry education are more often using advice from extension publications, magazines and newspapers while owners with higher forestry education prefer advice from forestry experts (Kuhns et al 1998). Salmon et al (2006) suggest that amenity focused landowners consider thinning to be detrimental due to insufficient knowledge in forestry. Landowners with knowledge of forestry and forest management are found to be more satisfied with the harvest results, and they tend to plan a harvest in the future (Henry and Bliss 1994).

\section{Typology analysis}

Some researchers have focused on describing private landowners' typologies. Greene and Blatner (1986) suggest that landowners’ management behavior can be predicted on segmentation group characteristics. These studies mostly distinguish landowners with production objectives (wood and non-wood) and consumption objectives (wood and non-wood goods and services) (Ní Dhubháin et al 2007), and look for information that could lead to better forest policies based on the landowner behavioral model (Hyberg and Holthausen 1989). Following the concept by Ní Dhubháin et al 2007 
selection of studies are presented in Table 1 according to owner type groups. Different authors have a different number of clusters or segmentations and they have named them differently, but general trends are similar.

Landowners with production goals (Table 1) are highly timber oriented (Butler et al 2007; Kliene et al 2000; Kluender and Walkingstick 2000). These owners are actively engaged in forest management activities (Butler et al 2007; Kendra and Hull 2005) and tend to have employed someone for managing their forestland (Kluender and Walkingstick 2000). These owners are most likely involved with extension programs and are not a target group for assistance programs (Butler et al 2007)

Non-timber goals refer to landowners who have not sold timber on their land (Kluender and Walkingstick 2000) and value amenity values (aesthetics and privacy) (Butler et al 2007; Kluender and Walkingstick 2000). These owners prefer to let the nature take its course, but some owners show interest to get more involved with some management activities (Kendra and. Hull 2005). These landowners are one of the most efficient target groups for extension services to promote desirable management behaviors (Butler et al 2007).

Landowners with multiple objectives are interested in a wide range of forest related benefits (Butler et al 2007; Kluender and Walkingstick 2000) and are found to be the largest group compared to others (Kliene et al 2000; Majumdar et al 2008). These landowners are actively involved with forest management operations and incentive programs (Majumdar et al 2008). Their high willingness to participate in management 
activities makes them the prime target group for extension services (Kendra and Hull 2005).

Table 1. Selection of landowners’ typology groups (Based on Ní Dhubháin et al 2007).

\begin{tabular}{|c|c|c|c|c|c|}
\hline \multirow[t]{2}{*}{ Paper } & \multirow{2}{*}{$\begin{array}{l}\text { Production } \\
\text { goals }\end{array}$} & \multicolumn{4}{|c|}{ Consumption goals } \\
\hline & & Wood & Non-timber goals & $\begin{array}{c}\text { Multiple } \\
\text { objectives }\end{array}$ & Indifference \\
\hline $\begin{array}{l}\text { Butler et al } \\
\quad 2007\end{array}$ & $\begin{array}{l}\text { Supplemental } \\
\text { Income } \\
\text { Owners }\end{array}$ & & $\begin{array}{c}\text { Woodland } \\
\text { Retreat Owners }\end{array}$ & $\begin{array}{l}\text { Working } \\
\text { the Land } \\
\text { Owners }\end{array}$ & $\begin{array}{l}\text { Ready to } \\
\text { sell owners }\end{array}$ \\
\hline $\begin{array}{c}\text { Kluender and } \\
\text { Walkingstick } \\
2000\end{array}$ & $\begin{array}{l}\text { Timber } \\
\text { Managers }\end{array}$ & $\begin{array}{c}\text { Poor } \\
\text { Rural } \\
\text { Residents }\end{array}$ & $\begin{array}{c}\text { Resident } \\
\text { Conservationist }\end{array}$ & $\begin{array}{l}\text { The Affluent } \\
\text { Weekenders }\end{array}$ & \\
\hline $\begin{array}{l}\text { Majumdar et al } \\
2008\end{array}$ & Timber & & & $\begin{array}{l}\text { Multiple- } \\
\text { Objective }\end{array}$ & Non-timber \\
\hline $\begin{array}{l}\text { Salmon et al } \\
2006\end{array}$ & & & Amenity-focused & $\begin{array}{l}\text { Multiple- } \\
\text { benefit }\end{array}$ & $\begin{array}{c}\text { Passive } \\
\text { landowners }\end{array}$ \\
\hline $\begin{array}{l}\text { Kendra and } \\
\text { Hull } 2005\end{array}$ & Farmers & & $\begin{array}{l}\text { Preservationists, } \\
\text { Young Families }\end{array}$ & $\begin{array}{c}\text { Forest } \\
\text { Planners }\end{array}$ & $\begin{array}{l}\text { Absentees, } \\
\text { 'rofessionals }\end{array}$ \\
\hline $\begin{array}{l}\text { Kliene et al } \\
2000\end{array}$ & $\begin{array}{l}\text { Timber } \\
\text { producers }\end{array}$ & & Recreationists & $\begin{array}{c}\text { Multi- } \\
\text { objective } \\
\text { owners }\end{array}$ & $\begin{array}{l}\text { Passive } \\
\text { owners }\end{array}$ \\
\hline
\end{tabular}

Landowners in the indifference group are the least actively engaged in forest management activities (Majumdar et al 2008; Kendra and Hull 2005) with exceptions to pruning or cutting down dead trees (Kendra and Hull 2005). Frequent reasons stated by those landowners for not managing their land are simply never thought about it, do not consider the forest to be suitable for management or do not have enough time (Kendra and Hull 2005). These landowners are showing undesirable management attitudes and 
behavior, and therefore are the least attractive target group for forestry extension services (Butler et al 2007).

\section{Decision support}

Some studies have focused on landowners' perception of professional advice. Landowners' decision modes could be useful for extension services, providing decision aid for selecting the most efficient and flexible approach based on landowners' expectations (Hujala et al 2007). The continuum in Figure 1 represents landowners' dependence on professional advice found by (Hujala et al 2007; Hujala et al 2009).

The groups in Figure 1 are supported with landowners' and their forest holding characteristics, past forestry experience, preferred communication modes with experts, role of forest management plans and landowners' motivations (Hujala et al 2007). The landowners who are following modes in column I are described as strongly self-reliant (Hujala et al 2007). Landowners' decisions are made based on their own experiences and they prefer straight forward communication with experts and precise information (Hujala et al 2007; Hujala et al 2009). These owners do not differ in timber trading activities compared to other types, but they less likely have or have had a forest management plan and more than likely on their land (Hujala et al 2009).

The landowners who can be placed into groups in column IV, are eager to gain new knowledge about forestry and are looking for interactive field trips with forestry experts (Hujala et al 2007). These landowners are often using a forest management plan and are motivated to become confident in decision making based on consultancy with professional foresters (Hujala et al 2007; Hujala et al 2009). 
Landowners representing types in column V claim inadequate experience and/or low interest in forestry (Hujala et al 2007). These owners may show active engagement in silvicultural treatments (Hujala et al 2007), but they strongly rely on recommendations from forestry experts (Hujala et al 2007; Hujala et al 2009). Compared to other types, these owners most likely have or have had a forest management plan (Hujala et al 2009) but the plan is used by experts rather than owners (Hujala et al 2007).

\begin{tabular}{|c|c|c|c|c|c|}
\hline & I & II & III & IV & V \\
\hline $\begin{array}{l}\text { Hujala } \\
\text { et al } \\
2007\end{array}$ & Decisive & Pondering & Managing & Learning & Trusting \\
\hline & Decisive & & & & Trusting \\
\hline $\begin{array}{c}\text { Hujala } \\
\text { et al } \\
2009\end{array}$ & $\begin{array}{c}\text { Independent } \\
\text { managers }\end{array}$ & & & $\begin{array}{l}\text { Active } \\
\text { learners }\end{array}$ & $\begin{array}{l}\text { Trusting } \\
\text { Realizers }\end{array}$ \\
\hline
\end{tabular}

Figure 1. Hypothetical continuum of landowners' dependence on professional advice (Based on Hujala et al 2007). 


\section{Research Design}

This study involves the use of human subjects. Please find the Michigan Technological University Institutional Review Board (IRB) approval number M0392.

\section{Objectives}

For this study following objectives were stated:

- to investigate active NIPF's vision for healthy mature forests and their understanding of how to manage forest to get it to this state;

- to investigate what forest management practices they are using and whether they are or are not likely to lead to sustained yield management;

- to investigate their knowledge about forest management and how they make timber harvesting decisions.

In order to reach NIPFs who are actively involved in forest management I chose to study landowners who have had commercial timber harvesting or selective cutting done on their land. With this criterion I expected to eliminate less active managers and concentrate on more active managers. Improved knowledge about NIPF's intentions and forest management behavior could be useful for successful implementation of sustained

yield management. Furthermore knowing NIPF’s forest management values and forestry knowledge could help extension staff and policy makers better communicate with these landowners.

\section{Study sample}

The interview sample for this study originated from a previous project about landowners in Michigan's eastern Upper Peninsula (48 landowners) and the northern 
Lower Peninsula (55 landowners). Sampling rules (Appendix 1) are described more in detail by Makinen (2010), full set of questions are presented in Appendix 2. For this study I chose a selective sample of landowners from the 97 individuals from the previous sample who have had commercial timber harvesting or selective cutting done on their land.

\section{Interviews, data collection}

Between August and October 2011 we called 42 individuals and completed 30 semi-structured interviews. I conducted 17 of the interviews and an undergraduate research assistant conducted the remaining 13. Property owner contact information originated from the previous study. Phone numbers volunteered by landowners or generated through landline web searches were used in order to contact the individuals. On the first call we introduced the study, its relationship to the previous project, the main focus and asked landowners of their willingness to participate in the research. In the case of property owners agreeing they were also asked for their permission to tape record the responses, and for the best time to conduct the interview. The reasons for failing to conduct 12 interviews were landowners' time availability, low interest in the topic, outdated phone numbers of an inability to reach the individuals after multiple calls.

In the beginning three pilot interviews were conducted and used for evaluating and editing the questionnaire in order to form a final document (Appendix 3). This was used for all subsequent interviews. Pilot interviews were included in the analysis. Prior to each interview appropriate findings about the landowners from the previous study were 
analyzed. This information helped to learn about their management goals beforehand and utilize interview time to develop on specific topics.

At the beginning each interviewee was asked if they were comfortable with answers being recorded and read the confidentiality statement (Appendix 4) to get their consent for the interview. The discussion was directed according to the interview questionnaire and landowners were encouraged to discuss topics such as attitudes and beliefs towards forestry, forest management, forest management practices, redundant statement and future intentions. Interviews lasted from eight to 46 minutes with an average of approximately 20 minutes, depending on landowners' interest in the study topic and their time availability.

\section{Data analysis}

The service "Record My Calls" at www.recordmycalls.com was used to record the interviews. This service records phone conversations and allows one to download the audio file onto a computer. All the interviews were simultaneously transcribed with data collection. Next, responses from the transcribed interviews were labeled. An example of a label is: I12Q5 indicating the section of text comes from Interview 12 and a response for Question 5. After labeling all labeled files were sorted into 14 documents according to the interview question. Those documents allowed us to track responses from every interview to a specific question. Finally sorted files were used for coding the responses which allowed us to determine how many interviewees responded to each category of a specific question. 


\section{Data source}

Not all analyzed questions resulted in identifiable trends, therefore in this report results from following questions are presented:

Q2 What do you think a healthy, mature forest in the Great Lakes area should look like?

Q3 What conditions or events (if any) do you think are necessary for a healthy forest to mature?

Q4 What is, or are your goals for your forest?

Q6 You already told us (about previous harvest), did you do it yourself or did someone else do it? If someone else: Who? Who selected the trees to cut? What were the important factors for selecting the trees for harvest (maturity of the trees, improving the spacing between trees something like this)?

Q7 Have you used some forest management practices in the past 10-15 years that weren’t mentioned previously? (site preparation, seeding, planting, thinning, timber stand improvement, etc)? If yes: Can you describe what were you doing?

Did you use own work or contractor?

Q11 Can you explain to me what you know about forest management and what does it mean do you? (Give a probe if they don’t know what you're asking for.), If mentioned some knowledge: Where and how did you learn about it?

Q12 Have you heard the term “sustained yield management”? If yes: What have you heard about it? And have you implemented it in your forest?

Q13 What are some advantages and disadvantages of managing forests for timber? 
For addition, data about parcel size, place of residence, ownership duration, management activity, presence of forest management plan, whether professional advice was received or not, reasons for timber harvest, education level and bioenergy originates from the previous survey. 


\section{Results}

All identified patterns in interviewees responses are presented with the number of individuals who fit with the category, followed by the percentage of interviewees who responded to that specific question. Responses may have different numbers of interviewees because during some interviews a question might not have been asked or answered. If a question was not asked or answered the interviewee was considered as a non-respondent. Calculated percentages often add up to more than $100 \%$ because an interviewee could give more than one answer to a question. To illustrate the patterns I will selectively present quotes from interviews, where the interviewee response matched the identified trend.

Property owners from 15 Michigan counties were interviewed. Twenty-seven (90\%) of the landowners reported commercial timber harvesting and the rest had experience with selective cutting. Interviewed NIPFs tended to be well-educated. Eleven (38\%) had an undergraduate degree and three (10\%) had a master’s degree. Three (10\%) had an associate's degree. Interviewees tended to own their land for a long time. Eleven interviewees (50\%) have owned their land for more than 30 years and only two (9\%) interviewees have owned their land for less than ten years. Nine interviewees (41\%) owned the land between ten to 30 years. The range of parcel size among landowners varied from 26 to over 1,000 acres with an average of 133 acres. Half (15) of the interviewees reside on their land. Eight interviewees (31\%) had a forest management plan and 23 individuals (79\%) had met with a professional forester. 


\section{Landowners' motivations towards forestry}

To better understand landowners’ insight beliefs and motivations towards forestry, they were asked to describe their vision of a healthy mature forest and their knowledge of how to manage to get it to this point. They were also asked to describe their goals for their own forest property. The patterns, how landowners described the healthy mature forest are presented in Table 2. Eleven (38\%) interviewees described healthy mature forests as a combination of mature trees and undergrowth. They valued mature trees, but at the same time thought of younger trees as new forest generation or a food source for wild animals. One landowner defines a healthy mature forest as following:

I would say probably, it would have to have I'd say probably $30-40 \%$ of hardwoods, mature hardwoods. And then you'd have the younger trees coming up and there should be some uh, undergrowth for the vegetation and deer to you know be eating stuff. (Interview 8)

Table 2. Landowners preference for healthy mature forests in the Great Lakes area $(n=29)$.

\begin{tabular}{|l|c|c|}
\hline Preference & Responses (n) & Responses (\%) \\
\hline Mature trees with undergrowth & 11 & 38 \\
\hline Mixture of species and/or structure & 10 & 34 \\
\hline Managed stand & 4 & 14 \\
\hline Mature trees with minimum undergrowth & 4 & 14 \\
\hline Combination of natural and managed forest & 3 & 10 \\
\hline
\end{tabular}

A mixture of tree species and stand structure was mentioned by ten (34\%) interviewees. The interviewees most commonly valued different tree species, forest types 
and successional stages. Two examples of this statement are presented in the following quotes:

It's, well usually it's a in this area a mixed stand, you'll have, like I say you have your hard and soft maple, you're beech, a you have a some elm, elm is usually on the lower ground, wetter ground. You've got some black cherry. And in some of your lower ground you run into a black ash or white ash. And that pretty much, we got basswood here too. Basswood seems to grow on high ground and lower ground so... (Interview 2)

Well, variety or diversity, you know, if you're looking at... Generally speaking, it would be diversity with different forest types and different successional stages. (Interview 18)

Four (14\%) interviewees described mature forests through periodical cutting. An example of interviewee's response:

You know, there's a lot of over mature forest around, which is you know between the issues with the beech and issues with the ash and some sort of issues with the birch, which I'm not sure. Aren't just natural, and there's too much standing dead woods, so I guess my answer would be forest is healthy when it is cut periodically so that you don't have, I mean some standing dead wood okay but it shouldn't harvested by any means.(Interview 20)

Also four interviewees described the forest as a combination of mature trees with minimal undergrowth. A natural forest with some assistance was mentioned by three (10\%) interviewees. They valued the natural look of the forest but at the same time believed it could get this way through active management. Example are presented respectively below: 
... I think it's a mature forest, probably, I'd liked... to see, a getting a opinion from a forester at some point, to getting a opinion on which, do a select cutting on the hardwood on the second forty we, cause I'd like to maintain a canopy so that we don't get a lot brush and stuff growing up, that's one of the reasons I was looking into having some of the basswood cut because that's a less desirable wood and it is got such a, such a big canopy, that I didn't want to cut a lot of the maples, big old maples out of there, Cause I just wanted to maintain that canopy, keep the ground growth down to the minimum. But I haven't contacted with anybody on that. (Interview 22)

Okay, I would like to see it you know largely managed as naturally as possible. Appreciating the fact that you have to get something out of it and tree farming is perfectly acceptable done under appropriate guidelines and things like that. (Interview 4)

In general, interviewees' responses described two conditions for a healthy forest to mature. Twenty (77\%) individuals reported a necessity of some cutting regimen such as selective cutting or timber stand improvement. Landowners mostly talked about the commercial value of mature trees, improving growing conditions for younger growth and removing dead or diseased trees. The following quote is an example of how a landowner explains his view:

If you don't manage your forest correctly, you're not getting the value that is there. And I think your value of your forest will deteriorate if you don't harvest the mature timber and to let the younger growth become larger and more value. So I think you're just defeating the purpose if you're not, you know, managing things correctly. (Interview 19) 
A natural succession with some management assistance was reported by six (23\%)

interviewees. One of individuals answered:

I think, there should be some of both, I think that, I like the natural and the less we disturb it the better. But I also appreciate the value of the renewable resource, so I'm willing to compromise with the development or with commercial use of the forest as long as they're willing to allow me to have some of my space and they only develop as much as necessary. (Interview 4)

Seventeen (61\%) interviewees assessed themselves as "hands-on” managers. Six (21\%) interviewees viewed themselves as “hands-off” managers and five (18\%) individuals reported themselves to be somewhere in between.

Landowners’ main forest goals are presented in Table 3. Many interviewees gave multiple answers for this question. Thirteen (45\%) interviewees reported managing for timber as an important reason for owning the forestland. Eleven (38\%) interviewees reported that they enjoy aesthetics, recreation, wildlife or any combination of those values. Nine (31\%) interviewees stated that wildlife management for game species was their primary goal. Seven (24\%) said that they cut timber for personal use (firewood or construction material). Two examples for quotes are presented below:

If I knew of techniques or, there were things you know I knew to do to improve conditions mainly for wildlife I would do them. To be honest I really familiar with them at all, I grew up in the south side of [City], so, you know, this is the whole forestry experiences is fairly new to me. But I do get out I have a trail going through the woods that uh it will be, the dead fall that come cross it, I'll cut it off. And I keep the eye out for diseases and things like that, but it doesn't appear to, you know nothing's really hitting off individual trees that will die, but nothing of a blight type of thing. (Interview 14) 
I harvest a different areas, every year I have a different area that I harvest and as time permits uh, I'll prune up crop trees. I just enjoy working in the forest and I want to continue it as long as I can. And hopefully when it's passed down they continue it too. (Interview 17)

Table 3. Landowners' goals for their forest land $(\mathrm{n}=29)$.

\begin{tabular}{|l|c|c|}
\hline Goal & Responses (n) & Responses (\%) \\
\hline To mange for timber & 13 & 45 \\
\hline Aesthetics, recreation, wildlife & 11 & 38 \\
\hline To be a good parcel for hunting & 9 & 31 \\
\hline To harvest timber for personal use & 7 & 24 \\
\hline To pass to future generations & 4 & 14 \\
\hline To sell the land & 3 & 10 \\
\hline
\end{tabular}

\section{Landowners and forest management practices}

To identify landowners' forest management behavior, they were asked about past harvest activities and forest management practices on their land. Specifically about the timber harvest, landowners were asked who made the harvest, who selected the trees and what were the important factors for selecting the trees?

The majority of the NIPFs (90\%) hired someone else to carry out at least one of the timber harvest operations on their land. Twenty-one had dealt with a logging company and four reported that the harvest was done by a friend or family member from some logging company. Four (14\%) reported that they have experience doing the harvest on their own.

Landowners were asked about decision making during timber harvests. They were asked who made decisions about which trees to cut. The results are presented in Table 4. 
Seven (26\%) said that a decision of which trees to cut was made by someone from a logging company. Five (19\%) stated that a friend or family member working for a logging company was responsible for selecting trees to cut. Two responses by different landowners are presented below:

Mostly at that time I didn't know what I was doing and just had a logger come in. And we walked through it and he kinda pointed to this one and that one, this one and that one, and uh being ignorant you don't know what you don't know I just said okay and let it go at that. (Interview 26)

The logger did it like I said, a good friend of mine works for the guy. And he had a highest respect for him, been working for him for ten years. So I had the confidence they weren't going to take unfair advantage of me. And which is good because in that line of work there are a number of people who have reputations for taking advantages of you. I was happy that this guy was willing to do it, interested in doing it. So I felt fortunate that we had him to do it. (Interview 4)

Eight (30\%) interviewees were using a consulting forester. Following is an example of how one of the landowners described his timber sale:

We use a consulting forester to set up the sale. He marks the trees, he inventories it and he puts it up for a bid and we, our last sale, we had about five or six loggers bid on it. (Interview 1)

Four (15\%) interviewees reported that they made decisions on their own and three (11\%) individuals used some advice. An example of one response: 
No, I do that myself. Initially when I first started managing the forest I'd have a forester do it but then I learned myself how to do it so... (Interview 17)

Table 4. Person who makes decisions during the harvest $(\mathrm{n}=27)$.

\begin{tabular}{|l|c|c|}
\hline Individual & Responses (n) & Responses (\%) \\
\hline Logger & 7 & 26 \\
\hline Consulting forester & 8 & 30 \\
\hline Friend or family member from logging company & 5 & 19 \\
\hline On his own & 4 & 15 \\
\hline On his own with advice & 3 & 11 \\
\hline Clearcut & 1 & 4 \\
\hline
\end{tabular}

Most common reasons for timber harvest were to gain profit, reported by 27 (90\%) interviewees, and timber stand improvement, 11 (37\%) interviewees. Motivations for selecting trees to cut are presented in Table 5. Sixteen (59\%) interviewees considered tree maturity as an important factor for cutting. Their decisions were made based on tree size, market value and overall stand condition (risk for disease or wind damage etc). For example, one said:

The aspen were definitely mature. They were to the point where they were either going to get harvested or they were going to start blowing down and breaking off... They were extremely mature for around, anywhere around here they were big. And then I needed the money at the time too... (Interview 24)

Ten (37\%) individuals stated that they wanted to improve growing conditions for the remaining trees. Landowners mainly mentioned they wanted to regulate stand density, improve growing conditions for remaining trees, eliminate poorly growing trees or any 
combination of those reasons. Some landowners also mentioned financial gain as a goal for selective cutting. For an example an interviewee explained:

Right well the thickness of the forest, where they needed to be thinned out was probably the biggest thing. And then of course we, they, they it was also for profitability as well. You know the, the trees that were..., they might not have been so thick but they were nice and big and they were worth some money. So they also took those. So it was a little bit of both. We were trying to be, do a good thing for the forest but I was also trying to get some decent money off of it. (Interview 28)

Table 5. Reasons for selecting trees to cut $(n=27)$.

\begin{tabular}{|l|c|c|}
\hline Criterion & Responses (n) & Responses (\%) \\
\hline Maturity of trees & 16 & 59 \\
\hline Thinning, timber stand improvement & 11 & 41 \\
\hline $\begin{array}{l}\text { Removing undesired or favoring desirable } \\
\text { species }\end{array}$ & 4 & 15 \\
\hline Wildlife, hunting & 4 & 15 \\
\hline Recover the investment & 2 & 7 \\
\hline
\end{tabular}

Some landowners wanted to get rid of some certain tree species, such as poplar for example and to regenerate stand with more desirable trees. Four interviewees said they wanted to open up the canopy in order to get undergrowth for wild animals. An interviewee explained:

Cause it was mainly just a hard, or a mature forest and that there stuff, and I just wanted to get a little undergrowth you know for the partridge and deer and stuff like that. (Interview 16) 
Other forest management practices landowners stated that they have planted trees or improved wildlife. Planting trees was reported by 14 interviewees. Motivations for planting were: aesthetic values, windbreak, Christmas trees, food source for wild animals, investment etc. Nine interviewees mentioned that they have improved wildlife. They mostly planted apple or oak trees and established food plots. Five landowners mentioned that they occasionally cut down dead trees.

\section{Landowners and their knowledge in forestry}

To investigate landowners' knowledge of forest management, they were asked about their past management experience, their explanation of what forest management is, what they know about forestry and what it means to them, and possible advantages and/or disadvantages of managing it for timber.

Landowners were asked about their knowledge in forestry. Results are presented in Table 6. Four (14\%) interviewees had a degree in forestry and eight (26\%) interviewees reported little to no knowledge. Some of these landowners gave a curt assessment of what they know, others discussed various topics such as timber harvest, different forest uses, diseases, regeneration, etc. Following is an example how a landowner explains what he knows about forestry:

No, I have not had any particular education. I have not really been involved or anything, other than the saplings we bought and planted that didn't do very well. So no I haven't, I mean I know a number of people who are in the forest industry and over the years talking with them I have learned enough to know what I can, what direction to go in and sometimes are the things I can, I can, you know I have done number of things, I have taken a good advice for and accomplished so I have certain attitude towards it. But I'm just not an 
expert to know, you know, what would best regenerate after you cut the red pine, do you plant more red pine, I don't know? Isn't there a succession where it starts up with the grub pine, like jack pine? When it dies off you get a slightly more valuable species growing there and it grows until it dies and the climax forest is hardwood right? Isn't it how it supposed to go? (Interview 4)

Table 6. Landowners' forestry awareness $(\mathrm{n}=29)$.

\begin{tabular}{|l|c|c|}
\hline Awareness & Responses (n) & Responses (\%) \\
\hline Balance between different uses & 12 & 41 \\
\hline Little to no knowledge & 8 & 28 \\
\hline Maximizing monetary/useful values & 7 & 24 \\
\hline Degree in forestry & 4 & 14 \\
\hline Working in the woods & 4 & 14 \\
\hline
\end{tabular}

Four (14\%) individuals reported of having experience working in forestry. Their knowledge was self-taught or learned from older, more experienced colleagues. One interviewee explained:

Well, I grew up in the area and at that time a woods work was a one of the, there were farming and woods work in the area which were predominately the two things that people made their living at, so I kind a got accustomed with both of them. And I worked initially in the woods with guys who were kids who worked in the lumber camps. So I kind of learned from them. And the rest of it was self-taught. My dad... you know because we worked, we cut out, we cut lumber we cut fire wood out of our property so. (Interview 2)

Some landowners did not respond to the question about their knowledge in forest management, but discussed its meaning. Twelve (41\%) interviewees explained forest management as a balance between different uses, such as wildlife, recreation, timber 
production, social values etc. An example how an interviewee explains forest management:

Well, I would explain it as you know if there is forest you would decide what is the use of that forest? And it can be a forest that is managed for timber purposes, that you would go through different processes and treated differently than if you are managing wildlife for or managing forest for wildlife purposes. And I would say that would be uh, and then there's, you know as far the parks in that are concerned there are areas that you want to have them retain a you know total natural appearance that would be three purposes that I can think of... (Interview 14)

Seven (24\%) NIPFs described forest management as primarily maximizing a forest's monetary values. One explained:

Well, for me it would be... You know, for a person who doesn't really have forestry management education... It would be a forest that is managed through selective cutting to optimize uh, the growth and worth of the timber or the trees, the worth of the trees, which normally is timber. (Interview 9)

Landowners were asked to name advantages and disadvantages of managing forests for timber. Seventeen (57\%) individuals were able to list both. Twenty-seven (90\%) interviewees were able to name at least one advantage, and at least one disadvantage was named by 17 (57\%) interviewees. Results are presented in Table 7. Twelve (40\%) interviewees reported that a main advantage of managing forest for timber is increased stand value or future income. An example of how an interviewee discussed timber stand value: 
I manage mine so, you know I have a nice looking forest. And also you know I had matures and becomes veneer and it's much more profitable for sale, it's worth, you know the property would be worth more money. You know if timbers not cap up, there's a lot of wind falls and the, your value of the property goes considerably lower. So I would say the managing your timber is going to have direct relationship. You know to the to your land, to worth of your property. (Interview 11)

Table 7. Advantages and disadvantages of managing forest for timber $(n=30)$.

\begin{tabular}{|l|c|c|}
\hline Advantages & Responses (n) & Responses (\%) \\
\hline Higher income & 12 & 40 \\
\hline Harvest outcome & 12 & 40 \\
\hline Improved stand condition & 10 & 33 \\
\hline Renewable resource & 5 & 17 \\
\hline No advantages given & 3 & 10 \\
\hline Disadvantages & & \\
\hline Wrong management decisions & 15 & 50 \\
\hline Long term decisions & 7 & 23 \\
\hline No disadvantages given & 13 & 43 \\
\hline
\end{tabular}

Twelve (40\%) interviewees reported harvest outcome as an advantage of managing forests for timber. Interviewees mostly mentioned improved conditions for wildlife and the environment. Four interviewees mentioned both, increased stand value and harvest outcome as advantages. An example of the individual who only saw benefits in forest management:

Well the advantages are pretty obvious, I have my own sawmill and although I you know, don't do a lot of cutting I do some sell logs, I do some cutting myself and as time goes on we're getting more, more mature trees coming available to us I really don't see any disadvantages to it so win-win situation. The more you manage the better it's going to get. Although wildlife is 
secondary to timber management you know we enjoy hunting and, we leave um, we girdle some trees and leave them for, leave dent trees and dead trees. Although the diseased trees we try and take out. (Interview 17)

Ten (33\%) landowners reported improved growing conditions for future trees as an advantage of forest management. They mostly explained how selection cutting improves spacing between trees and how it helps to establish regeneration. Also maintaining the proper stand and helping younger trees to mature was mentioned by some landowners. Five (17\%) individuals reported a renewable resource as an advantage and explained it through firewood consumption. The following quote is an example of how a landowner explains their understanding of thinning goals:

I believe that if you selectively cut an area over, it gives the rest of the trees the opportunity to mature faster than they would if you didn't take out some trees... Cause it allows more light in areas, and stuff grows better as a result of thinning the forest a little bit. (Interview 15)

Fifteen (50\%) interviewees named wrong management decisions as a disadvantage. Their definitions for wrong management decisions were various. Landowners talked about erosion risk after the harvest, poor timber harvest practices, managing without asking advice and deterioration of forest stand due to high grading. Seven (23\%) interviewees reported that forest management takes a long time. An example of what an interviewee said:

Disadvantages are the landscape is altered and sometimes altered forever. So you take the change with the, the erosion can take place if you're not careful, 
blow downs on other trees you take away from cover that other trees provided. (Interview 12)

Landowners were asked about "sustained yield management”. Eleven (39\%) interviewees said that they have heard the term, and three of those 11 had a degree in forestry. Three landowners thought they have heard the term and 14 (50\%) individuals said they have never heard of it. When landowners were asked to explain what they know about sustained yield management, six landowners explained periodical thinning, removing mature trees, improving growing conditions or any combination of those. Five other individuals also mentioned thinning or periodical cutting and removing marketable trees, but they did not consider stand improvement and regeneration. An example of how an interviewee who never heard of the term was able to explain:

I haven't heard that term, but I mean, I think I'd be kind of familiar with it. And basically as, as the, the land reproduces itself to move a little farther and take maybe more, more mature um trees or whatever from it. Is that, am I on that, the track? ... To an extent. And just kind of like continuing to manage it but as the new growth comes, allow it to mature a little bit. And then find other select cuttings that may enhance the new mature uh, or the new growth. (Interview 21) 


\section{Landowners and bioenergy}

Sixty percent of interviewees had heard about the new bioenergy plant and 89\% would be willing to sell timber to biofuels. Interviewees were also asked about why or why not they would be interested in cutting trees for bioenergy, results are presented in Table 8. Ten (38\%) interviewees said that they would sell if the price were competitive. Two examples of interviewees' responses:

And then if I got back the proper...like if the money would be the same...if you know what I'm saying. If you're going to get rid of it...if one tree is worth 300 bucks and they're only paying 100 bucks, then probably not. I'd probably have to go with the normal...you know what I'm saying? ... I don't mind losing a little if it's all good for the environment and everything else. But I don't want to lose a whole lot. (Interview 8)

Sure. I realize that most of them buy from loggers, and not from the individual person. Very few large corporations buy from the small guy like me. Almost all of them have their network of loggers to bring them the logs. But I mean, if someone approached me directly about a venture, I would consider it...opening up dialog...I'll wait until I get some 12-14 inch diameter maples, and then I would start to get a couple loggers to take a look at it and see which one is the hungriest for it. But the guy did a good job who cut my trees 10 years ago. I might let them do it again. But yeah, I'd open up dialog. I'd talk to them if somebody wanted to take the survey to the next level. (Interview 12)

Six (23\%) interviewees would be willing to sell as long they could retain control over the harvest. Two responses by different landowners are presented below: 
I don't have any problem with who it would be. My main concern is not who, but it's how....to make sure that they do it to my specifications. So it's not saying that I wouldn't do it. You know, the paper mill doesn't have any ties to me. So whether it goes to a paper mill or down to a biomass production, that doesn't really make any difference. (Interview 6)

Yeah, I would do it on kind of a...I wouldn't go clearing areas out, but I'm quite certain that it could be done on kind of a select-cut basis. I know not on an every-year kind of basis, but rather every so often, clearing some areas out helps the wildlife habitat and it needs to be done. (Interview 14)

Table 8. Why or why not to cut trees for bioenergy $(n=26)$.

\begin{tabular}{|l|c|c|}
\hline Reasons & Responses (n) & Responses (\%) \\
\hline Competitive price & 10 & 38 \\
\hline Interviewee retain control, no clear cut & 6 & 23 \\
\hline Undesired trees, no commercial value & 4 & 15 \\
\hline Would only allow to do thinning & 3 & 12 \\
\hline Would think about pros and cons & 3 & 12 \\
\hline
\end{tabular}

Four (15\%) interviewees said that they would sell trees without commercial value and $3(12 \%)$ reported that they would sell trees for biofules as long as they do thinning to open up canopy. Following are examples of how two of the interviewees answered:

... for companies like that I'm not against using wood scraps or undesirable trees to... you know like the biomass plant in [Name], or the proposed plant it [Name]. And there's one in [Name]. I'm all in favor of those, but to convert the stuff to a fuel to propel your car is just ridiculous. (Interview 29)

I wouldn't let them come in and clear-cut it, but I'd let them take and improve my basal area. If my basal area is going to be so tight that my trees are going to be two feet apart, and they're going to grow to about four inches in 
diameter, then they're going to die. So why not come in there and take every other tree out? Just like they did with the jack pine plantations in the 30s and 40 s... they went in there and they took every other tree out. Then they went in there again and took every other tree out again, every 10 or 15 years. So now you have a nice stand of pines. (Interview 3 ) 


\section{Discussion}

The objective for my study was to learn more about NIPFs who considered themselves active forest managers, therefore interviewees were selected based on their past timber harvest activities. All landowners had experience with commercial timber harvesting or timber stand improvement practices. Interviewees in this study had a larger parcel size and owned their land for a longer time period than an average landowner in Michigan. Furthermore, results indicate that these landowners were better educated and more likely to be absentee owners than those surveyed by other researchers (Leatherberry et al. 1998; Potter-Witter 2005). These findings indicate more active engagement in forest management practices and are supported with results from other studies (Butler et al 2007; Butler 2008; Joshi; Arano 2009; Majumdar et al 2008). Studied landowners were more likely to have a written management plan and sought for professional advice than an average landowner. A positive correlation between parcel size and landowners’ likelihood to harvest timber, presence of forest management plan and use of forest management advice is found in studies by Butler et al (2007); Butler (2008); Majumdar et al (2008). However, it should be noted that most of those prior studies were based on randomized samples of NIPFs. This present study was not. My sample was taken from a larger sample, that was randomly selected, however, all the NIPFs I interviewed were selected because they represent landowners who show high engagement in forest management activities. Therefore, my interviewees would be expected to be quite different from those in the other studies. 
One of my aims was to better understand landowner values and attitudes in regards to forests and forest management. Interviewees described a mature forest as a combination of mature and young trees (38\%) or a mixture of different tree species, forest types and successional stages (34\%). Seventy-seven percent of the studied landowners reported that some cutting regimen is necessary for a forest to mature and $61 \%$ of the interviewees claimed themselves to be a "hands-on” manager. Interviewees' preference for uneven-aged forest structure and reported necessity of some cutting regimen seem to fit with the concept of sustained yield management. However, the popularity of canopy cover objectives such as aesthetics and wildlife might lead to insufficient regeneration (Munsell et al 2008). In contrast, Ericson et al (2002) found that most of the landowners in Michigan see themselves as hands-off managers.

Interviewees' motivations for owning the forest land were various and they often gave multiple answers. Interviewees mentioned managing forests for timber, enjoyment of aesthetics, recreation and wildlife, hunting and using timber for personal use. Interviewees had some common characteristics with timber oriented, non-timber goals and multiple objective landowners as described by Butler et al (2007); Kendra and Hull (2005); Kluender and Walkingstick (2000); Kliene et al (2000); Majumdar et al (2008) and Salmon et al (2006). It could be conclude that studied landowners have a high willingness to participate in management activities and they are an efficient target group for extension services for promoting desirable management behaviors.

With regard to timber harvesting, I was interested in the basics; how landowners select trees to cut. Fifty-nine percent of the individuals looked for tree maturity. Their 
decisions were made based on tree size, market value or tree vitality. Forty one percent of the interviewees were aiming for timber stand improvement, they mentioned regulation of stand density and removing trees with undesirable characteristics. Most common reasons for harvest were to gain profit (90\%) interviewees, and timber stand improvement (37\%). Decision over harvestable trees was made by a logger (48\%), forester (30\%), or landowner (26\%). Landowners who used foresters seemed to be more aware of its advantages. Some landowners mentioned how foresters marked the trees and put them up for a bid where logging companies have to compete. Some of the landowners who had hired a logger for harvest operations explained that they had a family member or friend working in company, and they were sure the loggers were not going to take advantage of them. Interviewees were mostly satisfied with the forester or logger and very few landowners talked about bad experiences with timber harvest. If to simplify landowners' decision modes, described by Hujala et al (2007) and Hujala et al (2009) then approximately two-thirds of interviewees had some common characteristics with trusting realizers, (landowners with inadequate experience and/or low interest in forestry and who strongly rely on recommendations from forestry experts) (Hujala et al 2007; Hujala et al 2009). Trust in professional advice usually reflects scant experience with forestry or lack of interest to be involved with forestry (Hujala et al 2007). These owners may show engagement with forest management practices (Hujala et al 2007), but they strongly rely on recommendations from forestry experts (Hujala et al 2007; Hujala et al 2009). 
Interviewees were asked about their knowledge in forestry and what forest management meant to them. Forty one percent of the interviewees described forest management as a trade-off between different uses. They described how forests should be managed in a way that maximizes the benefits between various objectives. Interviewees mentioned timber production, wildlife, recreational or social values and needs or any combination of those. Interviewees tend to believe that timber production is also increasing their other forest related values. Interviewees who were able to discuss various topics might be more aware of different aspects of forest management. Twenty-four percent of the interviewees described forest management as maximizing monetary values, such as timber production. Landowners who were only able to think of timber production might be less aware of different management opportunities. Some landowners gave a self assessment on their knowledge in forestry. Eight (28\%) interviewees reported little or no knowledge. Four interviewees had a degree in forestry and four landowners reported experience working in forestry sector. When landowners were asked about sustained yield management, $45 \%$ of the interviewees reported that they have heard about it. When asked to explain, some landowners seemed to have a misconception of the idea. Some landowners mentioned aiming for a high rate of return or harvesting marketable trees. Private timberlands could be a potential supply source for a cellulosic ethanol facility. A previous study by Makinen (2010) identified landowners’ willingness to sell harvested materials for a bioenergy plant. Selling biomass or residuals is a new activity for NIPF owners, as is selling roundwood for bioenergy, as Mascoma plans to use hardwood roundwood in its plant. It can be assumed that private forest owners need 
more information and education about biomass markets. NIPF’s small holdings and uncertain plans for future timber harvest make them a challenging partner to co-operate. To ensure a reliable and continuous biomass supply, the cellulosic ethanol facility needs to include more stable companies which can ensure the availability of raw material. An opportunity to ensure a stable supply from private timber lands could be working together with forest owner associations and logging contractors. The bioenergy plant also needs to pay attention to already existing markets, pulp- and fire wood for example. Increased demand for raw material most likely increases the price for biomass and could negatively affect local communities. Interviewees would be willing to harvest timber for biofuels facility as long as it benefits landowners' management goals. Regards to sustained yield management, studied landowners are willing to sell by-products from selective cuttings or timber without commercial value. Interviewees are also willing to sell timber for biofuels if the price is competitive with already existing markets. 


\section{Conclusions}

Generally landowners described forests as a mixture between different tree species, forest types and successional stages. They often described the necessity of selective cutting, thinning or timber stand improvement for forests to mature and more than half of the landowners claimed themselves to be active managers. Landowners seemed to value both monetary and non-monetary values. Most commonly mentioned were timber production, wildlife, hunting, recreation and aesthetics. Studied landowners seem to have multiple objectives for their land and to be engaged in forest management practices. Some landowners mentioned lack of time or their high age as a reason to be less involved in management. Results suggest that studied landowners favor a managed forest. Several times interviewees mentioned unmanaged forests and how they see it as an unused resource. Interviewees tend to value continuous forest cover and appropriate management practices, which were often discussed.

All studied landowners had experience with timber harvests. The main reason they conducted harvest were to gain profit or improve forest growing conditions. Their decisions on which trees to cut were mainly driven by tree maturity or timber stand improvement. Some landowners conducted the harvest in order to improve conditions for wildlife. These findings suggest that sustained yield management could be appropriate for landowners in achieving their goals. Results also suggest that landowners, whether consciously or not, tended to manage their land for a sustained yield. Very few landowners made decisions on which trees to cut on their own. Trees for harvest were mostly selected by a forester or logger. Some interviewees were concerned that the logger 
may take advantage of them, although very few landowners described bad experiences with logging companies.

Studied landowners tend to understand the benefits of forest management, although foresters and loggers could help landowners with selecting appropriate management practices. Contractors should consider forest owners multiple objectives and more work would be needed in explaining how landowners could increase the value of their stand in the long run. In regards to the timber harvest, most of the studied landowners' decisions were influenced by foresters or loggers. To an average landowner forest management is based on trust in finding qualified people for doing the job. Extensions services could help landowners to find appropriate people to work and logging companies should consider that landowners are more willing to co-operate in the future if they have positive experiences from previous timber harvests.

The bioenergy plant could create acceptable market opportunities for NIPFs to sell residuals from timber harvest or timber stand improvement. A new market for undesirable tree species or trees with undesired characteristics could increase forest owners harvest activity. Using trees for biomass must not deteriorate landowners’ values in regards to forest, and all management activities should be taking into account landowners' preferences during the timber harvest. 


\section{References}

Arbogast, C., Jr. 1957. Marking guides for northern hardwoods under the selection system. USDA For. Serv. North Cent. For. Exp. Stn. Pap. 56.

Butler, B. J., Tyrrell, M., Feinberg, G., VanManen, S., Wiseman, L., Wallinger, S. 2007. Understanding and reaching family forest owners: lessons from social marketing research. Journal of Forestry. October/November: 348-357.

Butler, B.J. 2008. Family Forest Owners of the United States, 2006. Gen. Tech. Rep. NRS-27. Newtown Square, PA: U.S. Department of Agriculture, Forest Service, Northern Research Station. 72 p.

Butler, B.J. and E.C. Leatherberry. 2004. America’s family forest owners. J. For. 102(7): 4-9.

Erickson, D. L., Ryan, R. L., \& De Young, R. 2002. Woodlots in the rural landscape: Landowner motivations and management attitudes in a Michigan (USA) case study. Landscape and Urban Planning, 58, 101-112.

Greene, J.L.; Blatner, K.A. 1986. Identifying woodland owner characteristics associated with timber management. Forest Science. 32: 135-146.

Hansen, M.H., Brand, G.J. 2006. Michigan’s forest resources in 2004. Resour. Bull. NC255. St. Paul, MN: U.S. Department of Agriculture, Forest Service, North Central Research Station. 41 p. 
Henry, W., A., and J., C., Bliss. 1994. Timber Harvesting, Regeneration, and Best Management Practices Among West Central Alabama NIPF Owners. South. J. Appl. For. 18(3):116-121.

Hujala, T., Pykäälääinen, J., Tikkanen, J. (2007). Decision making among Finnish nonindustrial private forest owners: The role of professional opinion and desire to learn, Scandinavian Journal of Forest Research, 22:5, 454-463

Hujala, T., Tikkanen, J., Häänninen H., Virkkula O. (2009). Family forest owners,, perception of decision support, Scandinavian Journal of Forest Research, 24:5, 448460

Hyberg, B. T. \& Holthausen, D. M. 1989. The behavior of nonindustrial private forest landowners. Canadian Journal of Forest Research 19:1014-1023.

Hyberg, B.T. 1987. Multiattribute decision theory and forest management: A discussion and application. Forest Science 33 (4): 835-845.

Joshi, S. and K.G. Arano. 2009. Determinants of Private Forest Management Decisions: A Study on West Virginia NIPF Landowners. Forest Policy and Economics 11(2): 118-125.

Kendra, A. and R.B. Hull. 2005. Motivations and Behaviors of New Forest Owners in Virginia. Forest Science 51(2): 142-154. 
Kenefic, Laura S.; Nyland, Ralph D. 2005. Diameter-limit cutting and silviculture in northeastern forests: a primer for landowners, practitioners, and policymakers. NATP-02-05.

Kline, J., D., Alig, R., J., Johnson, R., L. 2000. Fostering the production of non-timber services among forest owners with heterogeneous objectives. Forest Science 46(2):302-311.

Kluender, R.A., AND T.L. Walkingstick. 2000. Rethinking how nonindustrial landowners view their lands. South. J. Appl. For. 24(3):150 -158.

Kuhns, M.R., M.W. Brunson and S.D. Roberts. 1998. Landowners’ educational needs and how foresters can respond to them. Journal of Forestry 96(8):38-43.

Leatherberry, Earl C.; Kingsley, Neal P.; Birch, Thomas W. 1998. Private timberland owners of Michigan, 1994. Resource Bulletin NC-191. St. Paul, MN: U.S. Dept. of Agriculture, Forest Service, North Central Forest Experiment Station.

Majumdar, I., L. Teeter, and B. Butler. 2008. Characterizing Family Forest Owners: A Cluster Analysis Approach. Forest Science 54(2):176-184.

Makinen, K. 2010. Balancing wildlife and bioenergy values on private forestlands in the eastern Upper Peninsula of Michigan. Thesis (M.S.) Michigan Technological University. 89 p. 
Mascoma Corporation. 2011. Our facilities.

[http://mascoma.com/pages/sub_business03.php] 11.22.2011

Munsell, J.F., R.H Germain, and I.A. Munn. 2008. A tale of two forests: Case study comparisons of sustained yield management on Mississippi and New York nonindustrial private forestland. Journal of Forestry. 106(8):431-439.

Munsell, J.F., R.H. Germain, V.A. Luzadis, and E. Bevilacqua. 2009. Owner intentions, previous harvests, and future timber yield on 50 working NIPF in New York State. Northern Journal of Applied Forestry. 26(2):45-51.

Ní Dhubháin, A., Cobanova, R., Karppinen, H., Mizaraite, D., Ritter, E., Slee., B and Wall, S. 2007, 'The values and Objectives of Private Forest Owners and Their Influence on Forestry Behaviour: The Implications for Entrepreneurship',_SmallScale Forestry, vol 6, pp. 347-357.

Nowak, Christopher A.; Marquis, David A. 1997. Distribution-of-cut guides for thinning in Allegheny hardwoods: a review. Res. Notes NE-362. Radnor, PA: U.S. Department of Agriculture, Forest Service, Northeastern Forest Experiment Station. $7 \mathrm{p}$.

Pan Y., Zhang Y, Butler B. J. 2007. Trends among family Forest owners in Alabama, 1994- 2004. Southern Journal of Applied Forestry, 31, 3:117-123.

Potter-Witter, K. 2005. A Cross Sectional Analysis of Michigan Non-Industrial Private Forest Landowners. Northern Journal of Applied Forestry. 22(2)132-138. 
Salmon, O., M. Brunson, and M. Kuhns. 2006. Benefit-Based Audience Segmentation: A Tool for Identifying Nonindustrial Private Forest (NIPF) Owner Education Needs. Journal of Forestry 104 (8):419-425.

Tubbs, Carl H. 1977. Manager's Handbook for Northern Hardwoods in the North Central States. USDA Forest Service General Technical Report NC-39. North Central Forest Experiment Station, St. Paul, MN. 29 pages.

USFS. 2011. United States Forest Service. National Woodland Owner Survey. Table maker. [http://www.fia.fs.fed.us/nwos/results/] 09.17.2011 


\section{Appendix}

Appendix 1. Initial sampling rules.

The previous project concentrated on landowners' values and beliefs on a variety of issues including land, forest and wildlife management and bioenergy. In the original study landowners were randomly selected by their parcels. Properties were selected from county plat books with sample sizes corresponding to the county’s privately owned timberland area and estimated number of rural property owners. All the selected plots were owned by individuals or married couples. Their mailing addresses were collected from county land records and phone numbers were obtained through a letter inviting them to participate in the future interview process.

“The Mathematical formula is simple. Each county’s private timberland area and estimated property owners are calculated as percentages of the totals for ALL counties in the study area. These percentages are then multiplied by the pre-determined total number of letters to be mailed. The mean of these two numbers is the sample size for that county”. (Makinen 2010)

"Property owner selection is based on the now-known sample size for each county. Using the Smith county example, we know we need 26 names of property owners, and we know the estimated number of private property owners is 5825. Divide 5825 by 26 to see that we would select every $224^{\text {th }}$ name from the owner index". (Makinen 2010) 
Appendix 2. Initial interview questionnaire.

\section{Interview Questions}

\section{A. General}

1. Can you tell us about your land? (Probes: How many acres do you own? How much is forested? What kinds of trees?)

2. What are your main reasons for owning your land? What are some of your favorite things about it? How long have you owned it?

3. What do you like to do on your land?

4. Some people view themselves as actively working with or managing their land to make it the way they want; others are more "hands-off". Do you see yourself as either of these?

5. What are your goals for your land? What would you like it to be like in 10-20 years? 


\section{B. Land Management [transition]}

6. Do you have any problems happening on your land or any concerns for the future?

(Probe: For example, some people we meet mention concerns about soil quality or erosion, insects or other nuisance species, tree diseases, fire, human activities, etc.) [If yes] Do you know of anything that could be done about it? Are you doing anything to address these concerns?

7. Have you ever met with a forester or logger to discuss management of your land? [If yes] Why and when? Do you have a management plan for your land? [If yes again] Can you tell us about the management plan and what it contains?

8. As you think about other people who own land, maybe neighbors or friends, are there people who come to mind that you think take really good care of their land? [If yes] What is it that you like about what they do?

9. Have you heard of the term "invasive species”? [If yes] What do you know about them? Do you know if you have any invasive species on your land? [If yes again] Are you concerned about these? 


\section{Forest Management [transition]}

10. Have you ever cut trees on your land? [If yes] When did that happen? For what purpose?

11. Do you plan to cut trees in the future? [If yes] Can you describe your plans? For what purpose, personal firewood or selling timber/pulp? How many acres? Would it be clearcut or selectively thinned?

12. [If any sort of harvest is planned] You mentioned...(things they value from question\#2)...Would you worry that cutting activities could impact those things? Are there things that could be done to minimize any possible impacts? What?

13. Have you heard of government programs where forest landowners get a tax break or shared costs to manage their forests? [If yes] What have you heard? [If no, explain that they exist]

14. Would you consider enrolling your land in any of these programs? Why or why not? 


\section{Wildlife management [transition]}

15. What kinds of wildlife do people see around here?

16 Are you interested in managing for wildlife on your land? [If yes] Do you feel you have a sense of things you could do on your land to attract wildlife or give them good habitat? Do you do this already? What do you do?

17. Are there any wetlands, streams, or ponds on your land? [If yes] Please tell us about them.

18. Are you familiar with any government programs that are available to help landowners manage for wildlife by improving habitats or restoring wetlands? [If yes] Which programs? Would you consider enrolling in one of these types of programs? Why or why not? [If no, explain that they exist] 


\section{E. Bioenergy [transition]}

19. Have you heard the phrase "energy independence"? [If yes] What have you heard? What does it mean to you? Do you think it's an important goal? Why or why not?

20. Have you heard of the term woody "bioenergy”? [If no, explain] It basically refers to energy produced from plant materials, such as trees, grasses, or corn. [If yes] How about woody biofuel or cellulosic ethanol? What have you heard?

21. There are several newer companies in the U.P. that use forest materials to produce energy, including a power plant in L'Anse, a couple of wood pellet manufacturers, and a facility in Kinross that will be producing cellulosic ethanol for cars. They might be interested in buying forest materials from landowners such as you to produce energy. Have you heard about these types of companies in our area? [If yes] What have you heard?

22. Do you think you would be interested in cutting trees from your land to sell to these types of companies? Why or why not?

23. What do you think of when you hear the terms "climate change" or "global warming”? [If not clear] Do you think it's not happening, is part of natural 
cycles, or is caused by humans? Do you think it will be a problem? [If yes] Would you be interested in managing your land to help prevent it? [If yes] Have you heard of carbon offset programs? [If yes] Would you be interested in selling carbon offsets from your land?

\section{G. Closing questions [transition]}

24. What do you do (or did) you or your spouse do for a living?

25. How far did you go in school?

26. Would you like any additional information about any programs related to land management?

27. Do you have any questions for us?

28. [Any questions from note-taker?] 
Appendix 3. Interview questionnaire, final document.

\section{General questions - Describing}

1. You already told us a few things about your land, but could you describe your forest? (What type of forest, mainly young or mature trees, even-aged or allaged? What are the main tree species?)

2. What do you think a healthy, mature forest in the Great Lakes area should look like?

3. What conditions or events (if any) do you think are necessary for a healthy forest to mature?

4. What is, or are your goals for your forest?

5. Will you or are you currently managing your forest to reach these conditions? If so: How? 


\section{Forest Management - Past}

6. You already told us (about previous harvest), did you do it yourself or did someone else do it? (If someone else: Who?) Who selected the trees to cut? What were the important factors for selecting the trees for harvest (maturity of the trees, improving the spacing between trees something like this)?

7. Have you used some forest management practices in the past 10-15 years that weren’t mentioned previously? (site preparation, seeding, planting, thinning, timber stand improvement, etc)?

a. If yes: Can you describe what were you doing? Did you use own work or contractor?

8. Do you think forest regeneration should occur naturally, with the assistance of a forester, or a mix of both?

9. Some landowners mentioned challenges when planning or carrying out management activities, such as a lack of capital or inadequate equipment. Have you encountered any of these, or anything similar?

10. Do any experiences with forest management come to mind that you could share with me? They can be positive or negative. 


\section{Knowledge and attitude}

11. Can you explain to me what you know about forest management and what does it mean do you? (Give a probe if they don’t know what you're asking for.)

a. If mentioned some knowledge: Where and how did you learn about it?

12. Have you heard the term "sustained yield management”?

a. If yes: What have you heard about it? And have you implemented it in your forest?

13. What are some advantages and disadvantages of managing forest for timber?

\section{Future plans}

14. You already told us (about future harvest plans), do you have any other plans for future forest management (site preparation, seeding, planting, thinning, timber stand improvement etc)? If so: Could you elaborate a little bit on those plans? 
Appendix 4. Confidentiality statement.

Thank you for agreeing to this interview, it is very helpful to us as we learn about landowners and their goals. I have a few questions for you that should take about $1 / 2$ hour. None of the questions are sensitive, but please know that what you say is confidential, your name will never be associated with any of your answers. It would be helpful to our research team if we could tape this interview in order to have a complete record of what you say. Are you comfortable with me taping the interview? If you have any questions or concerns about the interview, you can contact my supervisor [name] at Michigan Technological University - would you like her contact information? [e-mail address or phone number] 